\title{
Quantitative description of the pastoral economy of western Tuvan nomads
}

\author{
Paul L. Hooper \\ Chapman University; University of New Mexico, USA
}

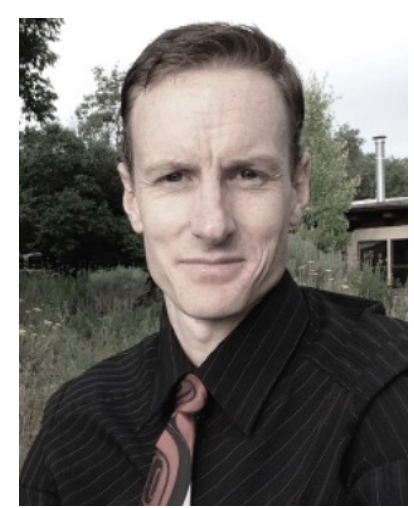

\begin{abstract}
Nomadic pastoralism persists at a substantial scale in Tuva and neighboring regions of Inner Asia. Tuvan pastoral lifeways reflect adaptations to both local environments and current economic realities. Much of our quantitative understanding of the economics of Tuvan nomads is derived from data collected in the first half of the 20th century. Accordingly, this paper provides an updated picture of the inner workings of nomadic households using data collected in Barun-Khemchik and Bai-Taiga provinces in 2013-2015. It analyzes herd composition and size, and compares the frequency of different animals kept today with values recorded in Tuva in 1916 and 1931. It then quantifies rates of provisioning hay and grain, and the production of meat and dairy products for consumption and sale. Finally, it characterizes typical costs of food, petrol, medicine, clothing, and school supplies faced by present-day herders. We advocate the collection of quantitative ethnographic data that can shed further light on the future of the Tuvan pastoralist niche.
\end{abstract}

Keywords: Tuva; Tuvans; nomads; animal husbandry; pastoralism; pastoralists; livestock farming; Inner Asia; economy of Tuva

HOOPER, Paul Lovell, Doctor of Philosophy, Researcher, Economic Science Institute, Chapman University; Adjunct Assistant Professor, Department of Anthropology, University of New Mexico. Postal address: One University Drive, Orange, California 92866, USA; MSC01-1040, Albuquerque, New Mexico 87131, USA. Tel.: +001 (714) 516-4513; +001 (505) 2774524. Email: p@systemsscience.co

Хупер Пол Лоуэл - доктор наук, научный сотрудник Института экономических наук Университета Чепмена; адъюнктассистент кафедры антропологии Университета Нью-Мексико (США). Адрес: One University Drive, Orange, California 92866, USA; MSC01-1040, Albuquerque, New Mexico 87131, USA. Тел.: +001 (714) 516-4513; +001 (505) 277-4524. Эл. адрес: p@ systemsscience.co 


\title{
Количественная характеристика скотоводческого хозяйства западных тувинцев-кочевников
}

\author{
Пол Л. Хупер \\ Университет Чепмена; Университет Нью-Мексико, США
}

\begin{abstract}
Кочевое скотоводство сохраняется в значительных масштабах в Туве и соседних регионах Внутренней Азии. Тувинский пастушеский образ жизни отражает адаптацию как к местным условиям, так и к современным экономическим реалиям. То, как мы понимаем экономику тувинских кочевников, в количественном отношении главным образом основано на данных, собранных в первой половине XX века. Соответственно, в данной работе представлена обновленная информация о жизни кочевых хозяйств на основе данных, собранных в Барун-Хемчикском и Бай-Тайгинском районах Тувы в 2013-2015 г2. В статье автор анализирует состав и размер стад, а также сравнивается частота содержания различных животных сегодня со значениями, зарегистрированными в Туве в 1916 и 1931 г2. Также количественно оцениваются нормы заготовки сена и зерна, а также производство мясных и молочных продуктов для потребления и продажи. Наконец, автор анализирует средние расходы на продовольствие, бензин, медикаменты, одежду и школьные принадлежности, с которыми сталкиваются современные пастухи. Автор выступает за сбор количественных этнографических данных, которые могут пролить новый свет на будущее скотоводческой ниши тувинской экономики.
\end{abstract}

Ключевые слова: Тува; тувинцы; кочевники; животноводство; скотоводческое хозяйство; скотоводство; внутренняя Азия; экономика Тувы

\section{Introduction}

The economics of nomadic Tuvan households were particularly well documented in the early $20^{\text {th }}$ century (Ermolaev, 1919ab; Tuvinskaya sel'skokhozyaistvennaya ... , 1933; Vainshtein, 1980). While Tuva has changed substantially since that time, ethnographic understanding of Tuvan pastoralists has lagged. We are prompted to ask: What dimensions of Tuvan pastoralism have changed in the last century? How do the size and composition of herds compare with those of the past? What contributions do present-day herds make to diet and to generation of income? Are pastoral incomes sufficient to cover modern-day expenses?

To begin to answer these questions, this paper provides a quantitative description of data collected through interviews at three study sites in western Tuva in 2013 and 2015 (Table 1). Interviews were conducted in collaboration with the senior members of each aal - a cluster of one or more households that camp together and pool livestock. Interviews recorded the number of animals owned; provision of hay and grain; meat and dairy products produced and sold; and major household expenses. This paper considers each of these dimensions of the herding economy in light of the long-term trajectory of Tuvan pastoralism using historical and contemporary data documented in Ermolaev (Ermolaev, 1919ab), the Tuvan Census of 1931 (Tuvinskaya sel'skokhozyaistvennaya ..., 1933); Vainshtein (Vainshtein, 1980); Sambuu and Titlyanova (Sambuu, Titlyanova 2014); Chysyma and Kuzmina (Chysyma, Kuzmina, 2019); and Taibyl et al. (Taibyl et al., 2019). 
Table 1. Study sites in western Tuva

Табл.1 Статистические данные о локациях, где проводилось исследование

\begin{tabular}{|c|c|c|c|c|}
\hline \multirow{2}{*}{ Site } & Khozhuun & Year & N Aals & N Households \\
\hline Site 1 & Barun-Khemchik & 2013 & 10 & 21 \\
\hline Site 2 & Barun-Khemchik & 2015 & 33 \\
\hline Site 3 & Bai-Taiga & 2015 & 15 & 38 \\
\hline
\end{tabular}
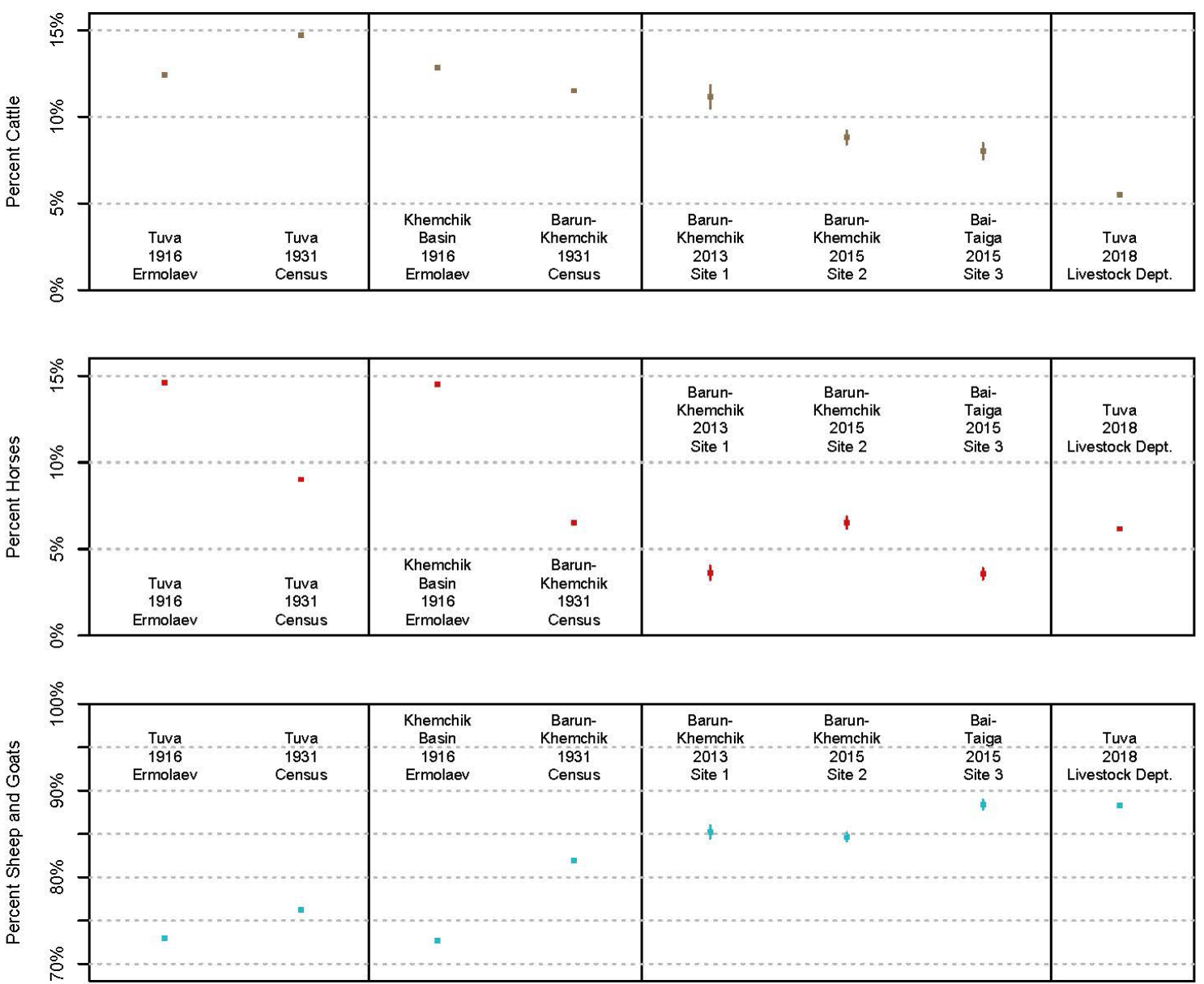

Figure 1. Historical herd compositions in comparison with the present sample.

Pис. 1. Состав стад в исторической перспективе и сравнении с современным состоянием.

The $y$-axis shows the number of adult animals as a percentage of the total number of cattle, horses, sheep and goats. For Sites 1, 2 and 3, error bars show \pm 1 standard error estimated from logistic regression using the glm $\left(\right.$ function in $R^{1}$.

${ }^{1} \mathrm{R}$ Core Team (2020) R: A Language and Environment for Statistical Computing. v. 4.0.2. Vienna: R Foundation for Statistical Computing. 


\section{Composition and Size of Herds}

The top panel of Figure 1 shows the proportion of adult cattle as a percentage of total adult animals (excluding yaks and camels ${ }^{1}$ ) in 1916, 1931, the current sample, and 2018. Ermolaev's estimates from 1916 indicate an average of $12.4 \%$ cattle for Tuva as a whole (Ermolaev, 1919ab). The 1931 Census showed a higher value of $14.7 \%$ cattle (Tuvinskaya sel'skokhozyaistvennaya ... , 1933). Vainshtein attributed this increase to state-sponsored encouragement of cattle herding in the early Soviet era. With respect to western Tuva in particular, the 1931 Census reported a value for Barun-Khemchik khozhuun (11.5\%) that was substantially lower than the 1931 whole-country mean (14.7\%; Vainshtein, 1980: 54-56).

In contrast to early $20^{\text {th }}$-century estimates, the $21^{\text {st }}$-century sample shows significantly lower proportions of cattle. Site 1 in Barun-Khemchik in 2013 shows a value of $11.1 \%$ ( $\pm 0.7 \mathrm{SE}$ ), slightly below the $11.5 \%$ reported for Barun-Khemchik in 1931. Sites 2 and 3 in Barun-Khemchik and Bai-Taiga in 2015 show even lower values of $8.8 \%( \pm 0.4 \mathrm{SE})$ and $8.0 \%$ ( $\pm 0.5 \mathrm{SE})$. This de-emphasis on cattle appears to mirror a wider trend: figures from the Livestock department of the Ministry of agriculture and food of the Republic of Tuva in 2018 indicate that cattle represent just 5.5\% of cattle, horses, sheep and goats in Tuva as a whole (Taibyl et al., 2019: 2).

With respect to horses, the middle panel of Figure 1 shows that the greatest number of horses was observed prior to the Soviet era. Ermolaev's 1916 estimates suggest that horses accounted for around $14.5 \%$ of livestock (excluding yaks and camels) in Tuva as a whole and in the Khemchik Valley (Ermolaev, 1919ab). By the 1931 Census, these values were dramatically lower: $9 \%$ for Tuva and $6.5 \%$ for Barun-Khemchik (Tuvinskaya sel'skokhozyaistvennaya ..., 1933; Vainshtein, 1980: 54-56).

The representation of horses in the present sample is as low or lower than in 1931, with values between 3.6\% and 6.5\% at the three sites. The mean for Tuva as a whole in 2018 was 6.1\% (Taibyl et al., 2019: 2). These low values are understandable in terms of greater reliance on motor vehicles in lieu of horses. They are, however, likely to be atypical of present-day herders that specialize in horses - such as those near the TannuOla mountains of southern Tuva - who are not represented in the current sample.

The bottom panel of Figure 1 describes the relative proportion of adult sheep and goats over time. While sheep and goats make up the lion's share of Tuvan herds, their numbers fluctuate based on time and place. It is notable that while the values were relatively low (around 75\%) for Tuva as a whole in the 1900s, in BarunKhemchik khozhuun specifically, sheep and goats made up 82\% of stock in 1931 (Vainshtein, 1980: 54-56). This emphasis on small stock (sher mal) in western Tuva is even greater in the 2013-2015 samples, with values of $85.2 \%( \pm 0.8 \mathrm{SE})$ at Site $1,84.7 \%( \pm 0.5 \mathrm{SE})$ at Site 2 , and $88.4 \%( \pm 0.6 \mathrm{SE})$ at Site 3 .

The movement toward a greater proportion of small stock has occurred across Tuva more generally, shifting from 76\% in 1931 to 88\% in 2018 (Vainshtein, 1980: 54-56; Taibyl et al., 2019: 2; Chysyma, Kuzmina, 2019: 61-62). These values, while significantly higher than the early $20^{\text {th }}$ century average, are still within the range of sub-regional variation observed in the pre-Soviet era: on the Boyan-Tugai River in Chadana in 1916, for example, Ermolaev documented herds comprised of $89.4 \%$ small stock, $4.0 \%$ cattle and $6.6 \%$ horses, a mix remarkably close to that of present western Tuvans (Ermolaev, 1919ab; Vainshstein, 1980: 55).

The average size of herds in the present study was 318.3 adult animals per aal, ranging from a minimum of 4 to a maximum of 1,012 animals. This equates to 76.5 bodo (a unit of livestock equivalent to one head of cattle: Vainshtein, 1980: 250) or 530 standard sheep units (defined in: Humphry, Sneath, 1999: 309). Vainshtein hypothesized that there were consistent relationships between herd size and composition: "[T]he richer herdsmen commonly had large numbers of sheep and goats, especially sheep; in the comparatively poor households the balance weighed noticeably in favour of cattle" (Vainshtein, 1980: 58). This pattern was borne out in the 1931 Census data, and can be understood in terms of the importance of maintaining a minimum number of cows to meet household demand for dairy products. In the past, oxen were also required as draft animals, a requirement that has been obviated by motorization and the collapse of traditional Tuvan agriculture (Ibid.: 57-59).

How do the size and composition of herds relate to each other in the present sample? The relationship between total number of animals and the subtotal for a given type of animal can be estimated using a regression model of the form $\log ($ subtotal $) \sim \log (\alpha)+\beta \times \log ($ total $)$. Because this function is equivalent to a scaling relationship of the form subtotal $\sim \alpha \times$ total $^{\beta}$, the variable $\beta$ is interpretable as an exponent in a

${ }^{1}$ One aal at Site 1 kept a herd of several hundred yaks as part of a government-sponsored program, while another aal at Site 3 kept two yaks. There were no camels at any of the sites. 
monotonic but potentially non-linear relationship between total and subtotal (Hooper et al., 2015). In the R programming language, this model can be estimated using the $\operatorname{lm}()$ function, with $95 \%$ confidence intervals (CIs) estimated using the confint() function ${ }^{1}$.

Table 2. Scaling relationships between total herd size and the number of cattle, horses, sheep and goats. Табл.2 Масштабное соотношение между общим числом голов в стаде и числом голов КРС, лошадей, овец и коз

A. Log-log Regression: Cattle $\sim \alpha \times$ Total $^{\beta}(N=69)$

\begin{tabular}{|c|l|l|l|}
\hline & Lower 95\% & Estimate & Upper 95\% \\
\hline Constant $\alpha$ & -0.934 & 0.024 & 0.983 \\
\hline Exponent $\beta$ & 0.322 & 0.511 & 0.701 \\
\hline
\end{tabular}

B. Log-log Regression: Horses $\sim \alpha \times$ Total $^{\beta}(N=60)$

\begin{tabular}{|c|l|l|l|}
\hline & Lower 95\% & Estimate & Upper 95\% \\
\hline Constant $\alpha$ & -1.599 & 0.037 & 1.674 \\
\hline Exponent $\beta$ & 0.037 & 0.358 & 0.680 \\
\hline
\end{tabular}

C. Log-log Regression: Sheep \& Goats $\sim \alpha \times \operatorname{Total}^{\beta}(N=70)$

\begin{tabular}{|l|l|l|l|}
\hline & Lower 95\% & Estimate & Upper 95\% \\
\hline Constant $\alpha$ & -0.597 & -0.355 & -0.223 \\
\hline Exponent $\beta$ & 0.985 & 1.033 & 1.080 \\
\hline
\end{tabular}
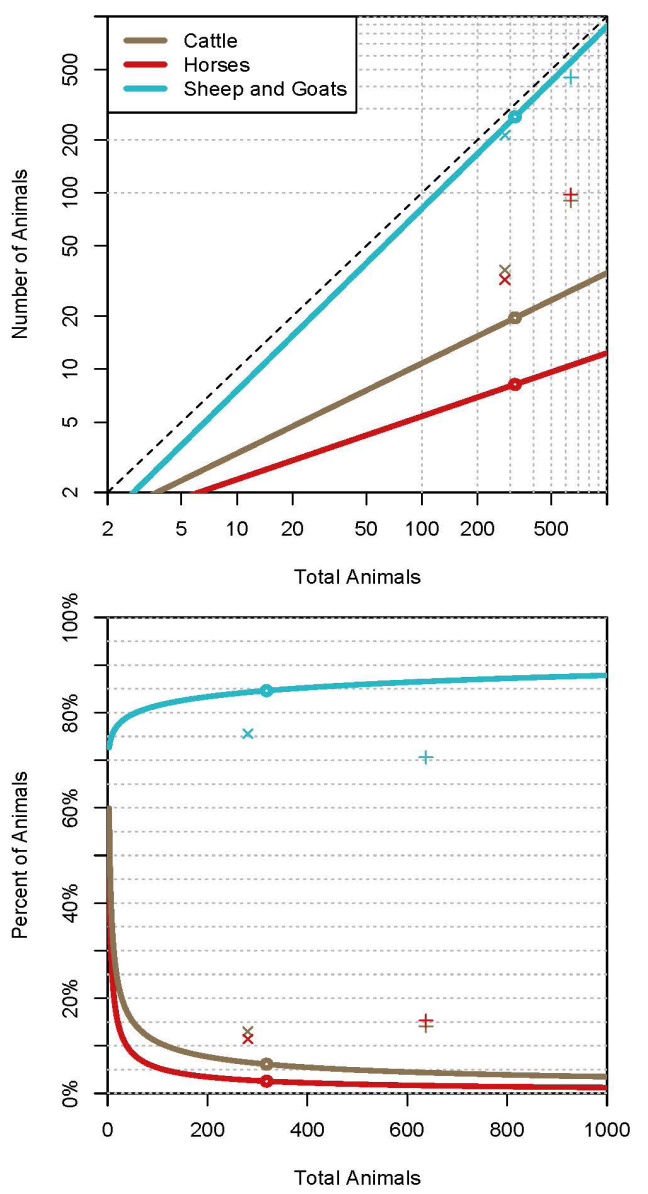

The scaling relationships estimated for cattle, horses, sheep and goats are given in Table 2 and plotted in Figure 2. The $21^{\text {st }}$-century data support Vainshtein's hypothesis: Table $2 \mathrm{~A}$ indicates that the number of cattle increases with approximately the square root of the total number of animals: Cattle $\sim 0.02 \times$ Total $^{0.51}$. The range of confidence intervals for the exponent in this model, $0.32-0.70$, indicates that this scaling relationship is significantly sub-linear $(<1)$.

To visualize this relationship, the brown line in the upper panel of Figure 2 plots cattle as a function of total animals in log-log space; the sub-linear scaling relationship for cattle appears as a shallow straight line with a slope less than one. The brown curve in the lower panel of Figure 2 shows how the proportion of cattle changes with herd size on a linear scale, confirming that the percent of cattle decreases in larger herds. Similar results are obtained for horses (Table 2B), but with an even lower exponent of 0.36 (0.04-0.68 CIs).

Figure 2. Relationships between herd size and number of cattle, horses, sheep and goats in 2013 and 2015.

Илл.2. Соотношение между числом голов стаде и числом голов КРС, лошадей, овеи и коз в 2013 и 2015.

The colored lines show the relationships estimated in Table 2. Open circles mark the mean herd size of aals in the present sample. The points marked $\times$ show the mean of households in the highest wealth category in 1931; the points marked + show the values for the aal of Kh. Mongush on the Ulatai River in the early 1900s (Vainshtein, 1980: 58, 89).

${ }^{1} \mathrm{R}$ Core Team (2020) R: A Language and Environment for Statistical Computing. v. 4.0.2. Vienna: R Foundation for Statistical Computing. 
Concomitant with these patterns for large stock, Table 2C and the turquoise lines in Figure 2 show that the number of small stock scales approximately linearly with total herd size. (While the confidence intervals for the exponent, $0.99-1.08$, overlap with 1 , the central estimate 1.03 is faintly super-linear, as implied by the sub-linear scaling of cattle and horses.) In other words, in both the 1930s and 2010s, wealthier Tuvan herders tended to have more sheep and goats - and proportionally fewer cattle and horses - compared to less wealthy herders. Consistent with this pattern, when total Tuvan livestock numbers fell around World War Two and again after 1991, the ratio of small stock to cattle also decreased. Conversely, periods of overall greater herd wealth - such as observed prior to World War Two, the 1960s through the 1980s, and in recent years - show relatively higher proportions of small stock (Sambuu, Titlyanova, 2014: 552).

Could larger herds alone account for the remarkably high proportion of sheep and goats today compared to the 1930s? In Figure 2 the points marked with $\times$ and + indicate the herd composition of notably wealthy families in the early 1900s (Vainshtein, 1980: 58, 89). Despite their large size, these historical herds still contain a greater proportion of cattle and horses (and fewer small stock) than expected from the current sample. This suggests that the shift from large to small stock over time is unlikely to be fully explained by changes in total livestock wealth.

\section{Provision of Hay and Feed}

Western Tuvan nomads regularly prepare hay to provision animals during winter. Hay fields are commonly located near winter or fall camps and irrigated with water from ditches, streams or rivers. The harvest and use of hay in Tuva is attested from at least the early $19^{\text {th }}$ century. Increases in hay production and investments in fixed winter camps were further encouraged by the state during the Soviet period (Vainshtein, 1980: 79-82). Data on the use of hay and feed were collected at Sites 2 and 3 in 2015.96\% of aals in this sample utilized hay, in contrast to only $47 \%$ of households in 1931 (Ibid.: 80). Among aals that used hay, 81\% harvested hay from their own fields, $12 \%$ purchased hay from the market, and 7\% used both harvested and purchased hay.

The mean amount of hay provisioned per aal was 14.2 ( $\pm 8.3 \mathrm{SD})$ metric tons. This number far outstrips the observation that prosperous herdsmen provisioned $100-200 \mathrm{~kg}$ of hay in the early $20^{\text {th }}$ century (Ibid.: 79 ). With a mean herd size of 72.7 bodo (or 520.6 sheep units) at Sites 2 and 3, this yields $195 \mathrm{~kg}$ of hay per bodo (or $27.2 \mathrm{~kg}$ per sheep unit). This is somewhat lower than the value of $40 \mathrm{~kg}$ per sheep unit documented in Solchur, southern Tuva, in 1993, and appears near the center of the distribution for other Inner Asian pastoralists (Humphry and Sneath, 1998: 266). In addition to hay, aals in this sample provisioned an average of 3.7 tons of grain and $720 \mathrm{~kg}$ of salt to their herds each year.

\section{Production of Dairy and Meat}

During the warm months in western Tuva, cattle provide a steady stream of milk that can be directly consumed or converted to an array of dairy products including cream, butter, curd, cheese, yogurt, milk tea, and fermented milk alcohol (araga). Biproducts from the preparation of one product are re-used in the production of others. Goats and yaks are also occasionally milked, but rarely in comparison with cattle. The data at Sites 2 and 3 show a mean of $1.98 \mathrm{~L}$ of milk produced per day per cow during the summer. With an average of 18.5 milk cows, each aal is expected to produce $36.6 \mathrm{~L}$ of milk per day, or roughly 25,000 dietary calories rich in fat, protein, probiotics, and micronutrients (Casimir, 1991; Shiby, Mishra, 2013).

These values are roughly consistent with Vainshtein's figure of 500 L produced per cow per year (Vainshtein, 1980: 104), and Osipova's assessment that a household of four would require 4 or 5 cows producing 8 to 10 L of milk per day (Osipova, 1961). The aals in this sample produced an average of $23.5 \mathrm{~L}$ of araga per week during the summer months, and a total of $45.7 \mathrm{~L}$ of butter for the year. Despite a smaller proportion of cattle in present-day herds, dairy production rates in western Tuva remain substantial.

Cattle, sheep, and goats are the principal sources of meat for western Tuvan nomads. Due to their size, cattle are typically slaughtered in winter when meat can be frozen and easily stored. Sheep and goats are typically slaughtered in the warmer seasons and consumed within a few days. Blood, offal, and meat are collected and prepared in ways that maximize food value and minimize waste. The aals at Sites 2 and 3 consumed an average of 2.5 out of 27 cattle, and 24 out of 279 small stock per year. Investments in social relationships with kin and other community members are made in the form of gifts of livestock and meat for ceremonies and special occasions. Aals in this sample gifted an average of 1.7 cattle and 13.2 small stock per year. 
Nomadic families generate income by sale of livestock to businesses, kin, and other buyers. Aals in this sample sold an average 3.5 head of cattle and 40.3 small stock per year. This generated an income of approximately P 65,000 from cattle and P 205,000 from small stock. 31\% of aals also sold milk products principally butter and araga-and generated an additional P 5,900 per year. All told, the mean yearly income from sale of meat and dairy was approximately P 272,000.

\section{Major Expenses}

While potentially self-sufficient in terms of diet and subsistence, present-day Tuvan families have preferences for goods and services - e. g. store-bought foods, consumer goods, education, medical care - that require currency and motivate the production of cash income. The abandonment, first, of traditional Tuvan agriculture, and second, of Soviet-era mechanized communal agriculture (with no subsequent recovery of traditional agriculture) has made nomads reliant on bread, flour, and other carbohydrates produced by commercial agriculture. Medical costs also weigh heavily on Tuvan families. Demand for these novel goods require levels of income that are difficult to generate through pastoralist activities alone.

Aals in the 2015 sample reported the following mean yearly costs:

$\begin{array}{ll}\text { Food } & \pm 82,000 \\ \text { Petrol } & \pm 77,000 \\ \text { Medicine } & \pm 66,000 \\ \text { Clothing } & \pm 62,000 \\ \text { School supplies } & \pm 28,000 \\ \text { Total } & \pm 315,000\end{array}$

We see that the sum of these expenses already exceeds the income from sales of meat and dairy calculated above; additional costs of purchased hay, grain, salt, veterinary medicine, equipment, vehicle repair, and other every-day expenses increase this total further.

Tuvan herders today clearly face a difficult financial reality. Interviewees lamented the low prices and high transaction costs that frustrate the conversion of pastoral wealth to money. Income generated in towns and cities is an important economic underpinning for many, if not most, nomadic Tuvan families. Consistent with this pattern, herders in this sample with the strongest links to towns also exhibited the largest herds and greatest overall wealth.

\section{Conclusions}

In response to the questions posed at the outset, the western Tuvan data suggest the following answers. Western Tuva has exhibited a trend toward proportionally more small stock (and fewer large stock) since the early $20^{\text {th }}$ century. In the last hundred years, this trend has become more pronounced in both western Tuva and Tuva as a whole. In both the early 1900s and today, wealthier herders keep relatively more sheep and goats and relatively fewer cattle and horses. Greater livestock wealth, however, does not fully explain the remarkably high proportion of sheep and goats observed in Tuvan herds today.

The analysis identifies a fragility in present-day Tuvan pastoralism. The inability to efficiently convert livestock into currency means that nomadic families struggle to cover the costs of education and consumer goods. As a result, measures that increase the profitability of pastoral products, lower barriers to affordable education, and improve access to quality health care are likely to be of particular benefit to the financial security of nomadic households.

High-resolution ethnographic data should continue to be collected to shed light on the long-term sustainability of nomadic lifeways in Tuva. Researchers can take advantage of new methods in statistics, mathematical modeling, and simulation using free programming languages such as R (R Core Team 2020). Quantitative studies of this kind can ultimately help identify factors that promote or harm the health and wellbeing of nomadic families. They will also play an important role in documenting the continued evolution of Tuvan culture and society in the $21^{\text {st }}$ century. 


\section{Acknowledgements}

Sincere thanks to the Tuvan families who helped collect these data; to Drs. Ilia Peiros, Anna Dybo, John Ziker, the Russian Academy of Sciences, and Tuvan State University for providing the opportunity for research; and to Adam Reynolds for organizing the data.

\section{REFERENCES}

Casimir, M. J. (1991) Flocks and Food: A Biocultural Approach to the Study of Pastoral Foodways. Köln, Böhlau Verlag. $327 \mathrm{p}$.

Chysyma, R. B. and Kuzmina, E. E. (2019) Innovatsionnoe razvitie zhivotnovodstva Respubliki Tyva [Innovative development of Animal Breeding in the Republic of Tuva]. Prirodnye resursy, sreda i obshchestvo, no. 1, pp. 59-65. (In Russ.).

Ermolaev, A. P. (1919a) Kratkii otchet ob issledovaniyakh v Uryankhaiskom krae v 1915-1918 [Brief report on research in the Uriankhai territory in 1915-1918]. Sibirskie zapiski, no. 4-5, pp. 35-39. (In Russ.).

Ermolaev, A. P. (1919b) Uryankhaiskii krai (materialy dlya kharakteristiki Uryankhaiskogo kraya $v$ torgovom otnoshenii) [Uriankhai territory: materials for the characteristics of the Uriankhai region in terms of trade)]. Minusink, Minusinsk Union of cooperatives. 27 p. (In Russ.).

Hooper, P. L., Demps, K., Gurven, M., Gerkey, D. and Kaplan, H. S. (2015) Skills, division of labour and economies of scale among Amazonian hunters and South Indian honey collectors. Philosophical Transactions of the Royal Society B: Biological Sciences, 370. DOI: https://www.doi.org/10.1098/rstb.2015.0008

Humphrey, C. and Sneath, D. (1999) The End of Nomadism? Society, State and the Environment in Inner Asia. Durham, Duke University Press. 355 p.

Osipova, V. (1961) Sel'skokhozyaistvennaya i demograficheskaya perepis' 1931 g. kak vazhneishii istochnik kharakteristiki ekonomicheskogo stroya sel'skogo khozyaistva Tuvy [Agricultural and demographic census of 1931 as the most important source of characteristics of the economic structure of Tuva's agriculture]. Uchenyee zapiski Tuvinskogo nauchno-issledovatel' skogo instituta yazyka, literatury, i istorii. Vol. 9, Kyzyl. Pp. 99-124. (In Russ.).

Sambuu, A. D., and Titlyanova, A. A. (2014) Vliianie sotsial'no-ekonomicheskogo razvitiia Respubliki Tyva na ee rastitel'nyi pokrov [The impact of socio-economic development of the Republic of Tuva on its plant cover]. Fundamental Research, no. 11 (3), pp. 550-555. (In Russ.).

Shiby, V. K. and Mishra, H. N. (2013) Fermented milks and milk products as functional foods - a review. Critical Reviews in Food Science and Nutrition, no. 53 (5), pp. 482-496.

Taibyl, R. S., Sevek, V. K., Sevek, R. M. and Darzhaa, Ch. B. (2019) Analysis of economic efficiency of livestock in the Republic of Tuva. IOP Conference Series: Earth and Environmental Science, vol. 320 (1) [online] Available at: https:// iopscience.iop.org/article/10.1088/1755-1315/320/1/012006

Tuvinskaya sel'skokhozyaistvennaya i demograficheskaya perepis' 1931 goda [Tuva agricultural and demographic census of 1931] (1933). Moscow, Published by the research Association for the study of national and colonial issues. 168 p. (In Russ.).

Vainshtein, S. I. (1980) Nomads of South Siberia: The Pastoral Economies of Tuva. C. Humphrey, ed. Cambridge: Cambridge University Press. 289 p.

Submission date: 03.08.2020.

\section{СПИСОК ЛИТЕРАТУРЫ}

Ермолаев, А. П. (1919а) Краткий отчет об исследованиях в Урянхайском крае в 1915-1918 гг. // Сибирские записки. № 4-5. С. 35-39.

Ермолаев, А. П. (1919b) Урянхайскій край : (Материалы для характеристики Урянхайского края в торговом отношении). Минусинск : Минусинский союз кооперативов. 27 с.

Осипова, В. (1961) Сельскохозяйственная и демографическая перепись 1931 г. как важнейший источник характеристики экономического строя сельского хозяйства Тувы // Ученые записки ТНИИЯЛИ. Вып. IX. С. 99-124.

Самбуу, А. Д., Титлянова, А. А. (2014) Влияние социально-экономического развития Республики Тыва на ее растительный покров // Фундаментальные исследования. № 11 (3). С. 550-555.

Тувинская сельскохозяйственная и демографическая перепись 1931 года (1933). М. : Издано Научно-исследовательской ассоциацией по изучению национальных и колониальных проблем. 168 с. 
Чысыма, Р. Б., Кузьмина, Е. Е. (2019) Инновационное развитие животноводства Республики Тыва // Природные ресурсы, среда и общество. № 1. С. 59-65.

Casimir, M. J. (1991) Flocks and Food: A Biocultural Approach to the Study of Pastoral Foodways. Köln : Böhlau Verlag. $327 \mathrm{p}$.

Hooper, P. L., Demps, K., Gurven, M., Gerkey, D., Kaplan, H. S. (2015) Skills, division of labour and economies of scale among Amazonian hunters and South Indian honey collectors // Philosophical Transactions of the Royal Society B: Biological Sciences, 370. DOI: https://www.doi.org/10.1098/rstb.2015.0008

Humphrey, C., Sneath, D. (1999) The End of Nomadism? Society, State and the Environment in Inner Asia. Durham : Duke University Press. 355 p.

Shiby, V. K. and Mishra, H. N. (2013) Fermented milks and milk products as functional foods - a review. Critical Reviews in Food Science and Nutrition. 53 (5), 482-496.

Taibyl, R. S., Sevek, V. K., Sevek, R. M., Darzhaa, Ch. B. (2019) Analysis of economic efficiency of livestock in the Republic of Tuva. IOP Conference Series: Earth and Environmental Science. Vol. 320 (1) [online] Available at: https://iopscience.iop. org/article/10.1088/1755-1315/320/1/012006

Vainshtein, S. I. (1980) Nomads of South Siberia: The Pastoral Economies of Tuva. C. Humphrey (ed.). Cambridge: Cambridge University Press. 289 p. 